35 Stern $\mathrm{Y}$, Alexander G, Prohovnik I, Stricks L, Link B, Lennon M, et al. Relationship between lifetime occupation and parietal flow. Neurology 1995 45: 55-60.

36 Gilleard C. Education and Alzheimer's disease: a review of recent international epidemiological studies. Aging Ment Health 1997; 1: 33-46.
37 Del Ser T, Hachinski V, Merskey H, Munoz DG. An autopsy-verified study of the effect of education on degenerative dementia. Brain 1999; 122: 2309-19.

38 Stern $Y$, Albert S, Tang MX, Tsai WY. Rate of memory decline in AD is related to education and occupation: cognitive reserve? Neurology 1999; 53 1942-7.

\section{poems \\ by doctors}

\title{
Endless Night
}

\section{Shaun Love}

These winter nights lie long and cold before you, like an icy road

that grants your well worn wheels no hold. And so you spin

around and round, tossed to and fro, in frozen sin.

You rev your engine, not to gain some hoped for ground, instead, to drain your heart of salted slushy pain.

But it won't bate.

For what goes round, comes back in veins and circulates.

Your heart alone can not reduce your load of pain. You need to use some organs that change old for new. Light, warm, fresh air

is waiting where you travel to on this black glacier.

An astronaut sent through such space, would, with drugs, dilute to trace the time and mind the travel takes. But drugs won't work. You'd fall asleep, only to wake back at the start.

Others sleep without a sound.

You hear their silence all around, sliding over the frictionless ground. Blind to night's stare,

deaf to their own baying hounds. Life is not fair.

So curse the Gods that made you be but gave you eyes so you could see, the distance that exists between the man you are and the man they made your eyes to see as mankind's par.

But pull and turn this rage inside to burn the bane of your poor mind. Your ice will melt. Your time will bide. The sun goes down.

Another summer sinks behind the long drawn blackout blind.

(c) Shaun Love 